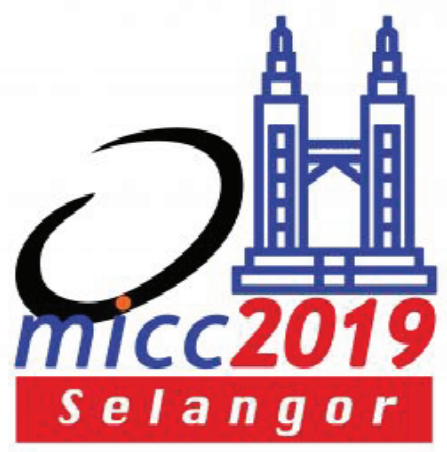

2019 14th IEEE Malaysia International Conference on Communications

Emerging Technologies in loE and $5 G$

2-4 December 2019

Bangi Resort Hotel, Bandar Baru Bangi, Selangor Malaysia

\title{
Organized by
}

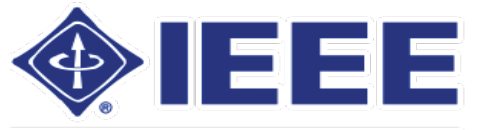

IEEE Malaysia ComSoc \& VTS Joint Chapter CIEEE $O A C^{\circ}$ IEEE MALAYSIA

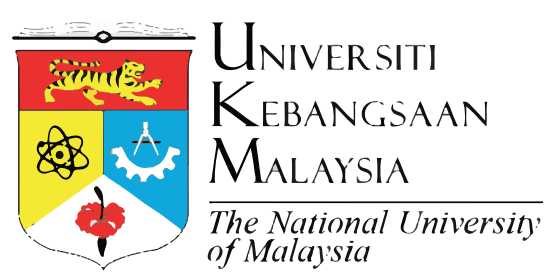




\section{TABLE OF CONTENTS}

Conference Background 2

Foreword by Dean of FKAB, UKM 3

Foreword by General Co-Chairs 5

Foreword by Conference Co-Chairs 6

Committee Members $\quad 8$

$\begin{array}{ll}\text { Keynote } 1 & 10\end{array}$

Keynote $2 \quad 11$

$\begin{array}{ll}\text { Conference Schedule } & 13\end{array}$

$\begin{array}{ll}\text { Technical Programme } & 16\end{array}$

Acknowledgements $\quad 21$

With Best Compliments 22 


\section{CONFERENCE BACKGROUND}

Malaysia International Conference on Communications (MICC) is fully sponsored by IEEE Malaysia Communication Society \& Vehicular Technology Society Joint Chapter (Com-VT) which was incepted in 1993. MICC has since been organized biennially, a few times in collaboration with other major conferences. In 1997, MICC was held in conjunction with IEEE 5th International Workshop on Intelligent Signal Processing and Communications Systems (ISPACS'97). In 2003 it was coorganized with IEEE 9th Asia-Pacific Conference on Communication (APCC03) and in 2005, the 7th MICC was organized in conjunction with IEEE 13th International Conference on Networks (ICON05). The 8th MICC in 2007 was cohosted with the 14th International Conference on Telecommunications (ITC07). Next, the 9th MICC in 2009 was held in Kuala Lumpur. The latest, the 10th MICC in 2011 was held in Kota Kinabalu that was collocated with the 17th Asia-Pacific Conference on Communications (APCC 2011). The 11th MICC2013 was held at Kuala Lumpur, Malaysia, and we have celebrated 20th year celebration of this conference. MICC conferences have been very well attended and supported by researchers from Asia-Pacific region and the world at large. The 12th MICC2015 and 13th MICC2017 was successfully held in Kuching, Sarawak and Johor Bahru, Johor.

Accepted papers will be published in the MICC2019 Conference Proceeding and will be submitted to IEEE Xplore for their consideration to be published. The proceedings also will be submitted for indexing and available at major academic databases. The conference and publication information are stated as below:

\author{
IEEE Catalog Number - USB \\ ISBN
}

IEEE Catalog Number - Xplore Compliant ISBN

\author{
: CFP1927C-USB \\ : 978-1-7281-4736-9
}

: CFP1927H-ART

: 978-1-7281-4737-6 


\section{FOREWORD BY DEAN OF FACULTY OF ENGINEERING \& BUILT ENVIRONMENT, UNIVERSITI KEBANGSAAN MALAYSIA}

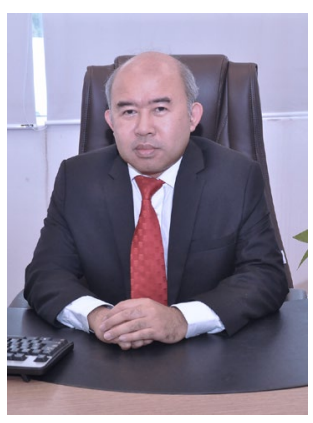

It is indeed a pleasure to be invited to address and officiate the 2019 14th IEEE Malaysia International Conference on Communications (MICC2019). May I take this opportunity as the Dean of Faculty of Engineering \& Built Environment, to welcome all international participants to Malaysia and say SELAMAT DATANG to MALAYSIA.

Congratulations to PAKET and IEEE Malaysia Communication Society \& Vehicular Technology Society Joint Chapter (Com-VT) for organizing this International Conference. I am sure it will be meaningful and fruitful conference given the presence of eminent leaders from the industries, academia and government agencies. Faculty of Engineering \& Built Environment, UKM has been continuously contributing to the development of emerging technologies both academically and scientific research through successful graduates and remarkable research publications.

One of the key enablers in Industrial Revolution 4.0 is an advanced mobile wireless technology. 5G marks an inflection point in the future of communications taking us into a dimension beyond our imagination. It is not only people are connected but all things are connected. These are among the wonders and benefits that $5 \mathrm{G}$ connectivity can unlock and it requires massive increase in the level of connectivity.

The change from $4 G$ to $5 G$ requires significant effort in research and development, industry-academia collaborations and the resources necessary to support this effort. MICC2019 is a premier forum for academicians, scientists, engineers and students to interact and disseminate information on the latest developments in communication and technological advances in 5G. The presence of international delegates will further benefit us as their inputs can be crucial in our efforts to collaborate, strategies and creates opportunities for more research in the emerging technologies related to Internet of Everything (IoE) and 5G. 
As Malaysia envision to become a developed nation by the year 2030 through its Shared Prosperity Vision 2030 framework, we are strongly committed to the development and advancement of basic and high technology areas. This will help to transform Malaysia into a high-income earning nation by focusing on high technology jobs that require specific skills rather than labor-intensive low skill jobs. Therefore, we actively seek for more international, industry-academia collaboration in all aspects of research and development activities while at the same time vigorously nurturing our own capabilities.

Finally, I hope the distinguished speakers and participants who are present here for the conference will have a productive and meaningful session. On that note, I hereby officiate the 2019 14th IEEE Malaysia International Conference on Communications (MICC2019).

Prof. Ir. Dr. Shahrir Abdullah

Dean

Faculty of Engineering and Built Environment

Universiti Kebangsaan Malaysia 


\section{FOREWORD BY GENERAL CO-CHAIRS}
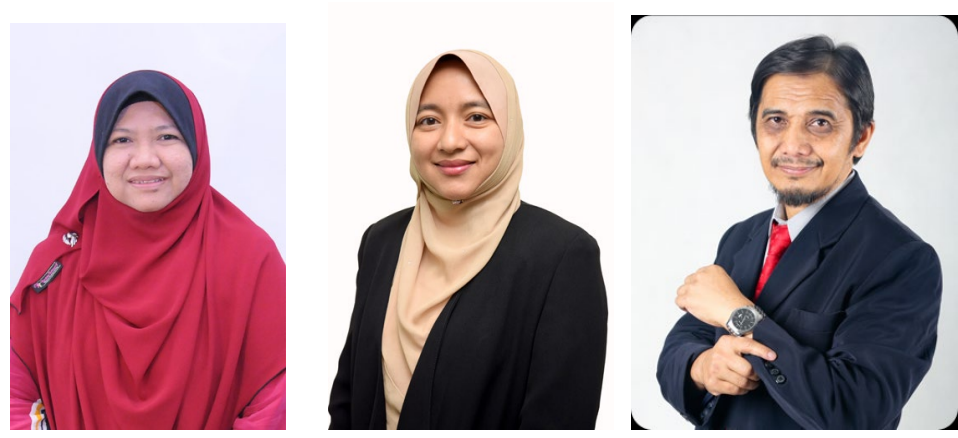

Welcome to MICC2019! Who would have thought we are just a few days away from the much awaited year 2020 - the year that we envisioned to be a developed nation and also the year for 5G deployment in Malaysia. As Ministry of Communications and Multimedia have coordinated 66 use cases with telcos, academia and regulatory bodies, all Malaysians are waiting in enthusiasm as what $5 \mathrm{G}$ will bring to the nation.

Researchers in the country are working for this issue for a while now, making sure that the technology will bring benefits to the people, especially to generate more job opportunities, increase quality of life, and enables the upcoming IR4.0. Whilst technology is impending, we must make sure that we also embrace Society 5.0, where communities are our focal point. The key question should be: 'How technologies can help improve our society?'.

This is the opportunities for researchers to engage with the local communities right from the beginning of our research projects, to make sure the projects will benefit the society. With the challenge of limited resources in the face of the current economic scenario, researchers should collaborate more, in order to increase synergy and optimise resources available to us.

Embracing all these challenges, let's have fun and embrace $5 \mathrm{G}$ and beyond!

Prof. Dr. Norbahiah Misran

Prof. Ir. Dr. Aduwati Sali

Prof. Dr. Mahamod Ismail 


\section{FOREWORD BY CONFERENCE CO-CHAIRS}
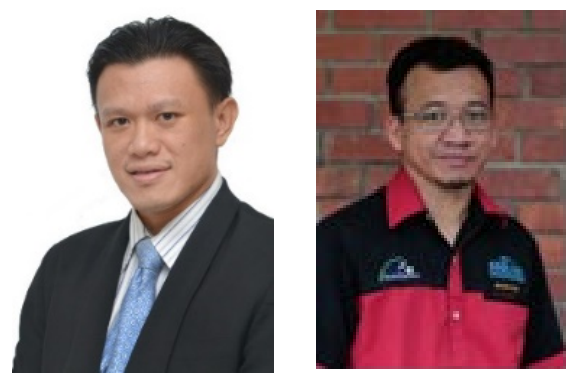

Assalamualaikum Warrahmatullahi Wabarakatuh. I am honoured and delighted to welcome you all to the Malaysia International Conference on Communications 2019 (MICC19). First and foremost, allow me to congratulate the organizers of MICC19, IEEE Communication Society and Vehicular Technology (ComsocVT) and Centre of Advanced Electronic and Communication Engineering (PAKET), Universiti Kebangsaan Malaysia for hosting this successful international event. On behalf of IEEE Malaysia, I would like to thank all of you for attending this premier event. I would also like to take this opportunity to welcome the official delegates, guest of honour, academician, researchers, lecturers, student, senior government officials, business leaders, who are present at today ceremony.

The series of IEEE ComsocVT Conferences, aimed at reinforcing scientific and technological collaboration between the universities, industry, government and research institutes, is known for providing state of the art information on current and future research activities, strategies and projects from around the globe with presentations from a variety of international speakers and researchers. Malaysia International Conference on Communications (MICC) is a flagship conference of IEEE Malaysia Communication Society \& Vehicular Technology Society Joint Chapter. The first MICC was successfully held in year 1993 at Kuala Lumpur, Malaysia, 12th MICC2015 in Kuching, Sarawak and 13th MICC2017 in Johor Bahru, Johor. Today, MICC2019 is held in Bangi, Selangor, Malaysia. Congratulation.

I am pleased to inform that our MICC2019 conference has received more than 40 papers from around the globe in various field of communication such as antennas, propagation and RF design, optical communications, advances in the 5G communications and others. With the theme "Emerging Technologies in IoE and 5G", we hope that researchers, scientists and industrially relevant could explore, cooperate, promote, and gain motivation to achieve societal sustainability goals. All accepted papers will be published in the MICC2019 conference proceeding and will be submitted to IEEE Xplore for publication consideration. 
The intention of IEEE ComsocVT remains to become a fully-fledged chapter investigating the latest various fields in communication and electronic of engineering. ComsocVT Chapter is a technical sub-unit of IEEE Malaysia Section, founded in year 1993 and the second largest group within the section technical societies in Malaysia. The Chapters provide the local link to the valuable resources available from the IEEE ComSocVT. Our chapter has outstanding engineering programs that feed the engineering community of Malaysia and provide the society members with valuable opportunities to the network globally.

I would like to convey my sincere gratitude to the committee members of MICC2019 for the commitment and hard work in organizing this conference. My deepest appreciation also goes to the supporters, International Advisory Committee, Keynote Speakers, reviewers and sponsors from all over the world for their support towards this conference.

Finally, I would like to thank you all participant at this conference for your support and to wish you an interesting and productive day.

Wassalam

Assoc.Prof.Dr.Mardeni Bin Roslee (Chair, IEEE Malaysia, ComsocVT)

Dr. Mohd Fais Mansor 


\title{
COMMITTEE MEMBERS
}

\author{
General Co-Chairs \\ Mahamod Ismail, Universiti Kebangsaan Malaysia, MALAYSIA \\ Aduwati Sali, Universiti Putra Malaysia, MALAYSIA \\ Norbahiah Misran, Universiti Kebangsaan Malaysia, MALAYSIA
}

\section{Conference Co-Chairs}

Mohd Fais Mansor, Universiti Kebangsaan Malaysia, MALAYSIA

Mardeni Roslee, Multimedia University, MALAYSIA

\section{Executive Secretary}

Mohd Hafiz Baharuddin, Universiti Kebangsaan Malaysia, MALAYSIA

\section{Treasurer}

Norazreen Abd Aziz, Universiti Kebangsaan Malaysia, MALAYSIA Nur Idora Abdul Razak, Universiti Teknologi MARA, MALAYSIA

\section{Technical Program}

Khaizuran Abdullah, International Islamic University of Malaysia, MALAYSIA

(Chair)

Nor Fadzilah Abdullah, Universiti Kebangsaan Malaysia, MALAYSIA

Rosdiadee Nordin, Universiti Kebangsaan Malaysia, MALAYSIA

\section{Publication}

Gan Kok Beng, Universiti Kebangsaan Malaysia, MALAYSIA Norhana Arsad, Universiti Kebangsaan Malaysia, MALAYSIA

\section{Tutorial}

Mohamad Huzaimy Jusoh, Universiti Teknologi MARA, MALAYSIA Nurul Mu'azzah Abdul Latiff, Universiti Teknologi malaysia, MALAYSIA

\section{Sponsorship (Exhibition) \& Patronage}

Iskandar Yahya, Universiti Kebangsaan Malaysia, MALAYSIA

Raja Zahilah Raja Mohd Radzi, Universiti Teknologi Malaysia, MALAYSIA

\section{Website Design \& Publicity}

Khairil Anuar, Multimedia University, MALAYSIA

Sawal Hamid Md Ali, Universiti Kebangsaan Malaysia, MALAYSIA

\section{Keynote and Industry Forum}

Azwan Mahmud, TM/MMU

Lee Ying Loong, Universiti Tunku Abdul Rahman, MALAYSIA 


\section{Logistic/Local Arrangement/ Secretariat}

Nasharuddin Zainal, Universiti Kebangsaan Malaysia, MALAYSIA (chair)

Mohd Huzairi Johari, Universiti Kebangsaan Malaysia, MALAYSIA

Siti Salasiah Mokri, Universiti Kebangsaan Malaysia, MALAYSIA

Syahirah Abd Halim, Universiti Kebangsaan Malaysia, MALAYSIA

Seri Mastura Mustaza, Universiti Kebangsaan Malaysia, MALAYSIA

Aida Baharuddin, Universiti Kebangsaan Malaysia, MALAYSIA

Siti Zaida Md Yasir, Universiti Kebangsaan Malaysia, MALAYSIA

Kamarulzaman Mat, Universiti Kebangsaan Malaysia, MALAYSIA 


\section{KEYNOTE 1}

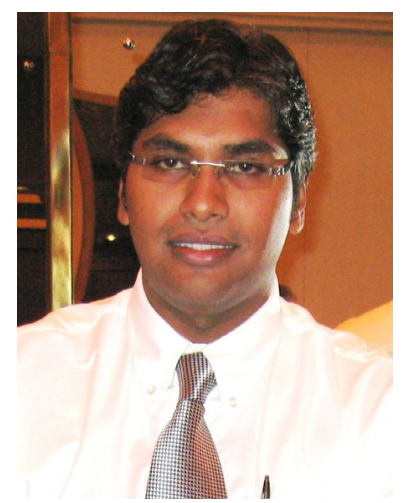

Gobinath S. G.

Ericsson Malaysia

Gobinath S. G. is the Head of Technology at Ericsson Malaysia. Mr. Gobi has over 24 years of experience in Wireless Telecommunication. Since, joining Ericsson in 1996, he has held multiple operational and engineering positions in different regions including Europe, Africa and Asia Pacific.

\section{G Switch Made Easy}

5G Market Outlook with highlights on Opportunities and Challenges from Consumer and Business Perspectives. 


\section{KEYNOTE 2}

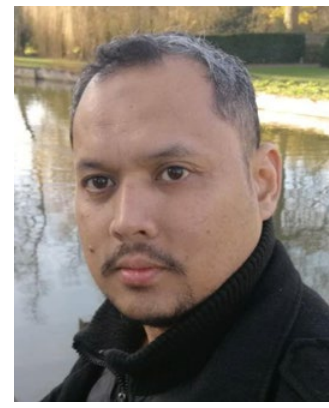

Dr. Azman Ali

Senior Consultant Key Account, TMOne

Dr Azman is a Senior Consultant for TM's Key Account overseeing Utilities, Logistic and Real Estates sectors. His current projects include Advanced Metering Infrastructure (AMI), Internet of Water and Analytic, Digital Workforce, SCADA loT integration as well as TM's 5G MCMC trial in Selangor and Langkawi. Azman joined Telekom Malaysia as a Network and Security Engineers in 1999 and has contributed towards the establishment of Malaysian's first Internet Exchange (MylX) and core Internet Services infrastructure for enterprises.

Dr Azman is currently the vice Secretary with Malaysian loT Association (MyloTA) and a member of the UK-Malaysia City of the Future Forum. Since 2017 he was appointed as KANZU Research Partner for Resilient City (Disaster Management Agenda under UTHM and Prime Minister Department).

Dr Azman obtained his PhD from Lancaster University, UK where he studied Autonomic Resilience Strategy to protect Internet Critical Infrastructure by leveraging on Evolving Machine Learning Technique. $\mathrm{He}$ also holds a Master Degree in Technology Management at EPFL, Switzerland majoring in Innovative Governance of large Urban Systems (IGLUS) during which he conducted field studies on various cities including Seoul, Istanbul, Moscow, St Petersburg, New York, Detroit and Cyberjaya/KL. 


\section{Delivering The Promise Of Technology On Advancing Humanity. A Case Study On Utility Industry In Malaysia}

The Internet of Everything allows seamless integration of cyber-physical systems which has been the signature attribute of IR4.0. However, while these technologies are important for economic growth their impacts on critical infrastructure such as water and energy are yet to be seen. The rising number of incidents on water contamination and casualties, frequent water supply shortage and staggering statistic of water lost in distribution are evidence of how our IR4.0 agenda might actually miss the whole point of what technology is meant for, improving our quality of lives and advancing humanity.

In Malaysia, almost one third of treated water are lost during distribution which can be translated into hundreds of millions in monetary values and loss of opportunity. With manual workforce, legacy OT infrastructure and high operational cost spent on energy, the industry is in dire need to address these limitations by leveraging on technology solution that can meet practical and economic sense.

In this presentation, we will share the industrial landscape of loT and how different sectors are impacted from the technology. We will take the audience through the transformation journey of Utilities Sector focusing on water industry as one of the most forgotten but yet vital and critical to our lives and economy. Some key challenges, solutions and results will be presented based on real pilot use cases that leverage on solution around Smart Water Grid, Digital Workforce and Analytic. At the end of this session, we will discuss some of the potential solutions or approaches that can further explored or researched to expedite the transformation of utilities industries. 
CONFERENCE SCHEDULE

\begin{tabular}{|c|c|c|}
\hline \multicolumn{3}{|c|}{ Monday, 02 Dec 2019} \\
\hline Time & & \\
\hline $8.00 \mathrm{am}-$ & \multicolumn{2}{|c|}{ Tutorial Registration } \\
\hline & Room Matahari 2 & Room Matahari 3 \\
\hline $\begin{array}{l}9.00 \mathrm{am}- \\
10.30 \mathrm{am}\end{array}$ & $\begin{array}{c}\text { Tutorial } 1 \\
\text { Modem SoC Design for } \\
\text { IEEE802.11n WLAN system } \\
\text { Jaeseok Kim }\end{array}$ & $\begin{array}{c}\text { Tutorial } 2 \\
\text { Non-Orthogonal } \\
\text { Multiple Access For 5G } \\
\text { And Beyond } \\
\text { Leow Chee Yen (Bruce) }\end{array}$ \\
\hline $\begin{array}{l}10.30 \mathrm{am}- \\
11.00 \mathrm{am}\end{array}$ & \multicolumn{2}{|c|}{ Tea Break } \\
\hline $\begin{array}{l}11.00 \mathrm{am}- \\
12.30 \mathrm{pm}\end{array}$ & $\begin{array}{c}\text { Tutorial } 1 \\
\text { Modem SoC Design for } \\
\text { IEEE802.11n WLAN system } \\
\text { Jaeseok Kim }\end{array}$ & $\begin{array}{c}\text { Tutorial } 2 \\
\text { Non-Orthogonal } \\
\text { Multiple Access For 5G } \\
\text { And Beyond } \\
\text { Leow Chee Yen (Bruce) }\end{array}$ \\
\hline $\begin{array}{l}12.30 \mathrm{pm}- \\
2.00 \mathrm{pm}\end{array}$ & \multicolumn{2}{|c|}{ Lunch } \\
\hline $\begin{array}{l}2.00 \mathrm{pm}- \\
3.30 \mathrm{pm}\end{array}$ & $\begin{array}{c}\text { Tutorial } 3 \\
\text { Cognitive radio of 5G } \\
\text { wireless Networks and GNU } \\
\text { Radio } \\
\text { Mardeni Roslee } \\
\end{array}$ & $\begin{array}{c}\text { Tutorial } 4 \\
\text { Broadband Multimedia } \\
\text { in Next-Gen Network } \\
\text { Sharifah Hafizah Syed } \\
\text { Ariffin } \\
\end{array}$ \\
\hline $\begin{array}{l}3.30 \mathrm{pm}- \\
4.00 \mathrm{pm}\end{array}$ & \multicolumn{2}{|c|}{ Tea Break } \\
\hline $\begin{array}{l}4.00 \mathrm{pm}- \\
5.30 \mathrm{pm}\end{array}$ & $\begin{array}{c}\text { Tutorial } 3 \\
\text { Cognitive radio of 5G } \\
\text { wireless Networks and GNU } \\
\text { Radio } \\
\text { Mardeni Roslee }\end{array}$ & $\begin{array}{c}\text { Tutorial } 4 \\
\text { Broadband Multimedia } \\
\text { in Next-Gen Network } \\
\text { Sharifah Hafizah Syed } \\
\text { Ariffin }\end{array}$ \\
\hline \multicolumn{3}{|c|}{ Tuesday, 03 Dec 2019} \\
\hline Time & \multicolumn{2}{|c|}{ Room Melur } \\
\hline $\begin{array}{l}7.30 \mathrm{am}- \\
8.30 \mathrm{am}\end{array}$ & \multicolumn{2}{|c|}{ Registration } \\
\hline
\end{tabular}




\begin{tabular}{|c|c|c|c|}
\hline $\begin{array}{l}8.30 \mathrm{am}- \\
9.00 \mathrm{am}\end{array}$ & \multicolumn{3}{|c|}{$\begin{array}{c}\text { Opening and Welcoming Remarks } \\
\text { Officiating: } \\
\text { Prof. Ir. Dr. Shahrir Abdullah } \\
\text { Dean, Faculty of Engineering \& Built Environment } \\
\text { Universiti Kebangsaan Malaysia }\end{array}$} \\
\hline $\begin{array}{l}9.00 \mathrm{am}- \\
9.45 \mathrm{am}\end{array}$ & \multicolumn{3}{|c|}{$\begin{array}{c}\text { Keynote 1: 5G Switch Made Easy } \\
\text { Gobinath S. G. } \\
\text { Ericsson Malaysia }\end{array}$} \\
\hline $\begin{array}{l}9.45 \mathrm{am}- \\
10.30 \mathrm{am}\end{array}$ & \multicolumn{3}{|c|}{$\begin{array}{l}\text { Keynote 2: Delivering The Promise Of Technology On } \\
\text { Advancing Humanity. A Case Study On Utility Industry } \\
\text { In Malaysia } \\
\text { Azman Ali } \\
\text { Senior Consultant Key Account, TMOne }\end{array}$} \\
\hline $\begin{array}{l}10.30 \mathrm{am}- \\
11.00 \mathrm{am}\end{array}$ & \multicolumn{3}{|c|}{ Tea Break } \\
\hline $\begin{array}{l}11.00 \mathrm{am}- \\
12.30 \mathrm{pm}\end{array}$ & \multicolumn{3}{|c|}{$\begin{array}{c}\text { Industry Forum: Realising loT and 5G for IR } \mathbf{4 . 0} \\
\text { Mazlan Abbas, FAVORIOT } \\
\text { Azman Ali, TMONE } \\
\text { Hazmin Abdul Rahim, SAP Malaysia } \\
\text { Chair: Borhanuddin Mohd Ali }\end{array}$} \\
\hline $\begin{array}{l}12.30 \mathrm{pm}- \\
2.00 \mathrm{pm}\end{array}$ & \multicolumn{3}{|c|}{ Lunch } \\
\hline & Room Melur & $\begin{array}{c}\text { Room } \\
\text { Matahari } 2\end{array}$ & $\begin{array}{c}\text { Room } \\
\text { Matahari } 3\end{array}$ \\
\hline $\begin{array}{l}2.00 \mathrm{pm}- \\
3.30 \mathrm{pm}\end{array}$ & Session 1.1 & Session 1.2 & Session 1.3 \\
\hline $\begin{array}{l}3.30 \mathrm{pm}- \\
4.00 \mathrm{pm}\end{array}$ & \multicolumn{3}{|c|}{ Tea Break } \\
\hline & & $\begin{array}{c}\text { Room } \\
\text { Matahari } 2\end{array}$ & $\begin{array}{c}\text { Room } \\
\text { Matahari } 3\end{array}$ \\
\hline $\begin{array}{l}4.00 \mathrm{pm}- \\
5.30 \mathrm{pm}\end{array}$ & & Session 2.2 & Session 2.3 \\
\hline $\begin{array}{l}7.30 \mathrm{pm}- \\
10.30 \mathrm{pm}\end{array}$ & \multicolumn{3}{|c|}{ Conference Dinner } \\
\hline
\end{tabular}


MICC 2019

\begin{tabular}{|l|c|}
\hline \multicolumn{2}{|c|}{ Wednesday, 04 Dec 2019 } \\
\hline $9.00 \mathrm{am}-$ & Technical Visit Registration \\
\hline $\begin{array}{l}9.30 \mathrm{am}- \\
10.00 \mathrm{am}\end{array}$ & Bus Travel \\
\hline $10.00 \mathrm{am}-$ & Technical Visit to \\
$12.00 \mathrm{pm}$ & Measat Teleport and Broadcast Centre, Cyberjaya \\
\hline $\begin{array}{l}12.00 \mathrm{pm}- \\
2.00 \mathrm{pm}\end{array}$ & Lunch at Putrajaya \\
\hline $2.00 \mathrm{pm}$ & Depart to Bangi Resort Hotel \\
\hline \multicolumn{2}{|c|}{} \\
\hline
\end{tabular}




\section{TECHNICAL PROGRAMME}

Tuesday, 03 Dec 2019

$\begin{array}{ll}\text { SESSION 1.1 } & \begin{array}{l}\text { Ad-hoc, Mesh, Machine-to-Machine and Sensor } \\ \text { Networks / Vehicular Communications, Networks } \\ \text { and Transportation Systems }\end{array} \\ \text { Venue } & \text { : Room Melur } \\ \text { Session Chair } & \begin{array}{l}\text { : Nor Fadzilah Abdullah } \\ \text { Time }\end{array} \\ \text { : } 2.00 \mathrm{pm}-3.30 \mathrm{pm}\end{array}$

\begin{tabular}{|c|c|}
\hline S1.1-1 & $\begin{array}{l}\text { Proactive Eavesdropping in Underlaid D2D Communication } \\
\text { Networks } \\
\text { Yingdong Hu (Nantong University, China); Ye Li (Nantong University, } \\
\text { China); Ruifeng Gao (Nantong University, China); Xiaodong Ji (Nantong } \\
\text { University, China); Shibing Zhang (Nantong University, China); Zhihua } \\
\text { Bao (Nantong University, China); Jun Zhu (University of British } \\
\text { Columbia, Canada) }\end{array}$ \\
\hline S1.1-2 & $\begin{array}{l}\text { Power Consumption Efficient Routing Protocol for Forest Fire } \\
\text { Detection based on Mobile Sensor Networks } \\
\text { Fahad Taha AL-Dhief (Universiti Teknologi Malaysia, Malaysia); Nurul } \\
\text { Mu'azzah Abdul Latiff (Universiti Teknologi Malaysia, Malaysia); Nik } \\
\text { Noordini Nik Abd Malik (Universiti Teknologi Malaysia, Malaysia); } \\
\text { Naseer Sabri (Computing and Information Technology, Sohar University, } \\
\text { Malaysia); Musatafa Abbas Abbood Albadr (Faculty of Information } \\
\text { Science and Technology Universiti Kebangsaan Malaysia, Malaysia); } \\
\text { Mustafa Jawad Abed (School of Electrical Engineering, Faculty of } \\
\text { Engineering, Universiti Teknologi Malaysia, Malaysia) }\end{array}$ \\
\hline S1.1-3 & $\begin{array}{l}\text { Cluster Head Selection Using Genetic Algorithm in Wireless } \\
\text { Sensor Network } \\
\text { Walaa Altakhayneh (UKM, Malaysia); Mahamod Ismail (Universiti } \\
\text { Kebangsaan Malaysia, Malaysia); Mohammed Altahrawi (UKM \& } \\
\text { UKM, Malaysia); Mohammed K. AbuFoul (University College of } \\
\text { Applied Science, Palestine) }\end{array}$ \\
\hline S1.1-4 & $\begin{array}{l}\text { AETD: An Application Aware, Energy Efficient Trajectory Design for } \\
\text { Flying Base Stations } \\
\text { Shavbo Salehi (Urmia University, Iran, Australia); Ayub Bokani } \\
\text { (Central Queensland University, Australia); Jahan Hassan (Central } \\
\text { Queensland University, Australia); Salil S Kanhere (UNSW Sydney, } \\
\text { Australia) }\end{array}$ \\
\hline S1.1-5 & $\begin{array}{l}\text { Data Dissemination of Vehicular Ad-Hoc Network in Highway } \\
\text { Scenario } \\
\text { Omer Abdulhae (National University of Malaysia (UKM), Malaysia); } \\
\text { Mahamod Ismail (Universiti Kebangsaan Malaysia, Malaysia); } \\
\text { Mohammed Altahrawi (UKM \& UKM, Malaysia); Mohammed Saad } \\
\text { (Alkitab University in Kirkuk, Malaysia) }\end{array}$ \\
\hline
\end{tabular}


Tuesday, 03 Dec 2019

$\begin{array}{ll}\text { SESSION 1.2 } & \begin{array}{l}\text { Antennas, Propagation and RF Design / Optical } \\ \text { Communications }\end{array} \\ \text { Venue } & : \text { Room Matahari } 2 \\ \text { Session Chair } & : \text { Mohd Hafiz Baharuddin } \\ \text { Time } & : 2.00 \mathrm{pm}-3.30 \mathrm{pm}\end{array}$

\begin{tabular}{|c|c|}
\hline S1.2-1 & $\begin{array}{l}\text { Compact Multiport Reflectometer for Microwave Material } \\
\text { Characterization } \\
\text { Obaidallah Ibrahim Mohamed Elshafiey (Universiti Teknologi Malaysia, } \\
\text { Skudai, Malaysia); Kok Yeow You (Universiti Teknologi Malaysia, } \\
\text { Malaysia) }\end{array}$ \\
\hline S1.2-2 & $\begin{array}{l}\text { HMSIW Bandpass Filter using Square Open Loop Resonator for } \\
\text { Short Range Device Applications } \\
\text { Dian Widi Astuti (Universitas Mercu Buana, Indonesia); Muslim Muslim } \\
\text { (Universitas Mercu Buana, Indonesia) }\end{array}$ \\
\hline S1.2-3 & $\begin{array}{l}\text { Capacitive Loading Effect of Dual Element Reconfigurable } \\
\text { Reflectarray Unit Cell } \\
\text { Mohammad Azrin Daud (Universiti Kebangsaan Malaysia, Malaysia); } \\
\text { Norbahiah Misran (Universiti Kebangsaan Malaysia, Malaysia); Mohd } \\
\text { Fais Mansor (Universiti Kebangsaan Malaysia, Malaysia); Muhammad } \\
\text { Yusof Ismail (Universiti Tun Hussein Onn Malaysia) }\end{array}$ \\
\hline S1.2-4 & $\begin{array}{l}\text { Bandwidth Enhancement of Dielectric Resonator Antenna Using } \\
\text { Complementary Hash Resonator } \\
\text { Aymen Dheyaa Khaleel (Universiti Kebangsaan Malaysia, Malaysia); } \\
\text { Mohd Fais Mansor (Universiti Kebangsaan Malaysia, Malaysia); } \\
\text { Norbahiah Misran (Universiti Kebangsaan Malaysia, Malaysia); } \\
\text { Mohammad Tariqul Islam (Universiti Kebangsaan Malaysia \& Universiti } \\
\text { Kebangsaan Malaysia, Malaysia) }\end{array}$ \\
\hline S1.2-5 & $\begin{array}{l}\text { Investigation of Q-switched and Mode-Locked Erbium Doped Fiber } \\
\text { Laser Using Graphene oxide-Saturable Absorber } \\
\text { Belal Ahmed Hamida G. Allah (International Islamic University, Malaysia); } \\
\text { Mahamat Omer (IIUM, Malaysia); Sheroz Khan (Inetrnational Islamic } \\
\text { University Malaysia, Malaysia); Tawfig A Eltaif (Multimedia University, } \\
\text { Malaysia) }\end{array}$ \\
\hline S1.2-6 & $\begin{array}{l}\text { Analyzing the effects of LED lamp arrangements on performance of } \\
\text { an indoor Visible Light Communication system } \\
\text { Komal Masroor (Universiti Teknologi PETRONAS, Malaysia); Varun Jeoti } \\
\text { (University Teknologi PETRONAS, Malaysia); Micheal Drieberg } \\
\text { (Universiti Teknologi PETRONAS, Malaysia) }\end{array}$ \\
\hline
\end{tabular}


Tuesday, 03 Dec 2019

$\begin{array}{ll}\text { SESSION 1.3 } & \begin{array}{l}\text { Cooperative Communications, Distributed MIMO } \\ \text { and Relaying / Special Track on Future Trends in } \\ \text { Internet of Things Technologies }\end{array} \\ \text { Venue } & \text { : Room Matahari 3 } \\ \text { Session Chair } & : \text { Khaizuran Abdullah } \\ \text { Time } & : 2.00 \mathrm{pm}-3.30 \mathrm{pm}\end{array}$

\begin{tabular}{|c|c|}
\hline S1.3-1 & $\begin{array}{l}\text { DDT-based Chaotic Interleaver Aided Cooperative OFDM } \\
\text { System } \\
\text { Shahid Manzoor (UCSI Universiti Kuala Lumpur, Malaysia); Noor S } \\
\text { Othman (Universiti Tenaga Nasional, Malaysia); Muhammad Asif } \\
\text { Khan (University of Engineering and Technology Taxila Pakistan, } \\
\text { Malaysia); Asim Ali (University of WAH, Pakistan) }\end{array}$ \\
\hline S1.3-2 & $\begin{array}{l}\text { An loT Based Smart Lighting System Based on Human Activity } \\
\text { Noorfazila Kamal (Universiti Kebangsaan Malaysia, Malaysia); } \\
\text { Kalaivani Chellappan (Universiti Kebangsaan Malaysia \& Faculty of } \\
\text { Engineering \& Built Environment, Malaysia) }\end{array}$ \\
\hline S1.3-3 & $\begin{array}{l}\text { Internet of Medical Things (IoMT) for Patient Healthcare } \\
\text { Monitoring System } \\
\text { Asma' Sharipudin (Universiti Sains Malaysia, Malaysia); Widad } \\
\text { Ismail (Engineering Campus, Universiti Sains Malaysia, Malaysia) }\end{array}$ \\
\hline S1.3-4 & $\begin{array}{l}\text { Smart Micro-Grid Delivery Response System via Internet of } \\
\text { Things } \\
\text { Nik Noordini Nik Abd Malik (Universiti Teknologi Malaysia, } \\
\text { Malaysia); Nurul Mu'azzah Abdul Latiff (Universiti Teknologi } \\
\text { Malaysia, Malaysia); Dalila Mat Said (Universiti Teknologi Malaysia, } \\
\text { Malaysia); Shipun Anuar Hamzah (Universiti Tun Hussein Onn Hen } \\
\text { Malaysia \& Faculty of Eletrical and Electronic Engineering (FKEE), } \\
\text { Malaysia); Nur Amanina Md Khir (Universiti Teknologi Malaysia, } \\
\text { Malaysia) }\end{array}$ \\
\hline S1.3-5 & $\begin{array}{l}\text { Reliable and low-latency routing mechanism for loT-based } \\
\text { networks } \\
\text { Mohammed Mahyoub (King Fahd University for Petroleum and } \\
\text { Minerals, Saudi Arabia); Ashraf Mahmoud (KFUPM, Saudi Arabia); } \\
\text { Marwan Abu-Amara (King Fahd University of Petroleum \& Minerals, } \\
\text { Saudi Arabia); Tarek Rahil Sheltami (KFUPM, Saudi Arabia) }\end{array}$ \\
\hline
\end{tabular}


Tuesday, 03 Dec 2019

$\begin{array}{ll}\text { SESSION 2.1 } & \begin{array}{l}\text { Future Trends and Emerging Technologies I } \\ \text { Special Track on Recent Advances in the 5G } \\ \text { Communications }\end{array} \\ \text { Venue } & \text { : Room Matahari } 2 \\ \text { Session Chair } & \begin{array}{l}\text { : Khairil Anuar } \\ \text { Time }\end{array} \\ \text { : } 4.00 \mathrm{pm}-5.30 \mathrm{pm}\end{array}$

\begin{tabular}{|c|l|}
\hline S2.1-1 & $\begin{array}{l}\text { Approximate Matrix Inversion Methods vs. Approximate } \\
\text { Message Passing (AMP) for massive MIMO Detectors } \\
\text { Mahmoud A. M. Allbreem (A'Sharqiyah University (ASU), Oman); } \\
\text { Ayman A. El-Saleh (A'Sharqiyah University (ASU), Oman) }\end{array}$ \\
\hline S2.1-2 & $\begin{array}{l}\text { Hybrid Precoding Using Projection-aided Block } \\
\text { Diagonalization for MmWave MU-MIMO Systems } \\
\text { Minjung Cho (Yonsei University, Korea); Hyukyeon Lee (Yonsei } \\
\text { University, Korea); Kyung Mook Oh (Yonsei University, Korea); } \\
\text { Jaeseok Kim (Yonsei University, Korea) }\end{array}$ \\
\hline S2.1-3 & $\begin{array}{l}\text { Performance of MIMO DWT for Millimeter Wave } \\
\text { Communication System } \\
\text { Nagma Parveen (International IIlamic University Malaysia, } \\
\text { Malaysia); Rounaqul Islam Boby (International Islamic University } \\
\text { Malaysia, Malaysia); Md Rafiqul Ilam (International Islamic } \\
\text { University Malaysia, Malaysia); Khaizuran Abdullah (International } \\
\text { Islamic University Malaysia, Malaysia) }\end{array}$ \\
\hline S2.1-4 & $\begin{array}{l}\text { Performance Evaluation of 5G Technology at 26 GHz and 41 } \\
\text { GHz: The Case of Suburban Tropical Areas in Indonesia } \\
\text { Muhammad Suryanegara (Universitas Indonesia, Indonesia); } \\
\text { Muhamad Asvial (Universitas Indonesia, Indonesia); Akmal Hugo } \\
\text { Prasetyo (N/A, Indonesia) }\end{array}$ \\
\hline S2.1-5 & $\begin{array}{l}\text { Resource Allocation Algorithm for D2D Communication in } \\
\text { Cellular Networks based on Hungarian Algorithm } \\
\text { Fareha Nizam (Multimedia University, Malaysia); Mardeni Roslee } \\
\text { (MMU, Malaysia); Zubaida Yusoff (Multimedia University, } \\
\text { Malaysia); Khairil Anuar (Multimedia Universiti, Malaysia) }\end{array}$ \\
\hline
\end{tabular}


Tuesday, 03 Dec 2019

$\begin{array}{ll}\text { SESSION 2.2 } & \begin{array}{l}\text { Spectrum Efficient Management, Sensing and } \\ \text { Cognitive Radio / Wireless \& Radio Access } \\ \text { Technologies }\end{array} \\ \text { Venue } & : \text { Room Matahari } 3 \\ \text { Session Chair } & : \text { Lee Ying Loong } \\ \text { Time } & : 4.00 \mathrm{pm}-5.30 \mathrm{pm}\end{array}$

\begin{tabular}{|c|c|}
\hline S2.2-1 & $\begin{array}{l}\text { Factors that Impact LoRa loT Communication Technology } \\
\text { Olakunle Elijah (University Teknologi Malaysia, Malaysia); Tharek } \\
\text { Abdul Rahman (Wireless Communication Centre, Malaysia); Ahmad } \\
\text { Haziq Irfan Saharuddin (Universiti Teknologi Malaysia \& Wireless } \\
\text { Communication Centre, Malaysia); Fatin Nasuha Khairodin } \\
\text { (Universiti Teknologi Malaysia, Malaysia) }\end{array}$ \\
\hline S2.2-2 & $\begin{array}{l}\text { Performance of Practical Multiuser MIMO Networks with Limited } \\
\text { CSI Feedback } \\
\text { Vei Hung Lee (Multimedia University, Malaysia); Ivan Ku (Multimedia } \\
\text { University, Malaysia); Ayman A. El-Saleh (A'Sharqiyah University } \\
\text { (ASU), Oman); Tuan Anh Le (Middlesex University, United Kingdom } \\
\text { (Great Britain)); Mohamad Yusoff Alias (Multimedia University, } \\
\text { Malaysia); Nur Idora Abdul Razak (Universiti Teknologi MARA, } \\
\text { Malaysia) }\end{array}$ \\
\hline S2.2-3 & $\begin{array}{l}\text { An Efficient Method for Resource Allocation and User Pairing in } \\
\text { Downlink Non-Orthogonal Multiple Access System } \\
\text { Zuhura J. Ali, Ms. (43400 Serdang \& University Putra Malaysia, } \\
\text { Malaysia); Nor Kamariah Nordin (Universiti Putra Malaysia, } \\
\text { Malaysia); Aduwati Sali (UPM, Malaysia); Fazirulhisyam Hashim } \\
\text { (Universiti Putra Malaysia, Malaysia); Mohammed Balfaqih } \\
\text { (University of Jeddah \& South Ural State University, Saudi Arabia) }\end{array}$ \\
\hline S2.2-4 & $\begin{array}{l}\text { Power Spectral Density and Spectral Efficiency Analysis in } \\
\text { Line-of-Sight } 2.6 \text { GHz Beamforming Femtocell Networks } \\
\text { Khalid Sheikhidris Mohamed (Multimedia University, Malaysia); } \\
\text { Mohamad Yusoff Alias (Multimedia University, Malaysia); Mardeni } \\
\text { Roslee (MMU, Malaysia) }\end{array}$ \\
\hline S2.2-5 & $\begin{array}{l}\text { Device-to-Device Communication Assisted by Selective DTF } \\
\text { Relay for MIMO Cooperative System } \\
\text { Pratap Khuntia (Nit Silchar, India); Ranjay Hazra (Nit Silchar, India) }\end{array}$ \\
\hline
\end{tabular}




\section{ACKNOWLEDGEMENTS}

IEEE ComSoc and VT Joint Chapter, Malaysia

Department of Electrical, Electronic and System

Engineering

Faculty of Engineering and Built Environment, Universiti Kebangsaan Malaysia

Measat Teleport and Broadcast Centre, Cyberjaya

Reviewers

Keynote Speakers

Industry Forum Panels 
MICC 2019

\section{With Best Compliments FROM}

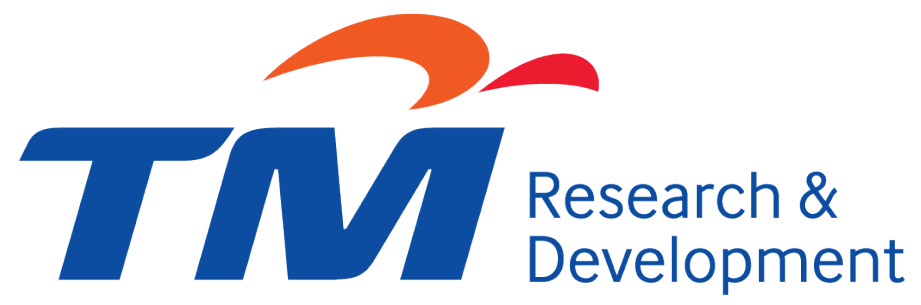

